WellBeing International

WBI Studies Repository

$11-20-1981$

\title{
Social, Spacing, and Cooperative Behavior of the Collared Peccary, Tayassu tajacu
}

John A. Byers

University of Idaho

Marc Bekoff

University of Colorado

Follow this and additional works at: https://www.wellbeingintlstudiesrepository.org/acwp_ena

Part of the Animal Studies Commons, Behavior and Ethology Commons, and the Comparative Psychology Commons

\section{Recommended Citation}

Byers, J. A., \& Bekoff, M. (1981). Social, spacing, and cooperative behavior of the collared peccary, Tayassu tajacu. Journal of Mammalogy, 62(4), 767-785.

This material is brought to you for free and open access by WellBeing International. It has been accepted for inclusion by an authorized administrator of the WBI Studies Repository. For more information, please contact wbisr-info@wellbeingintl.org.

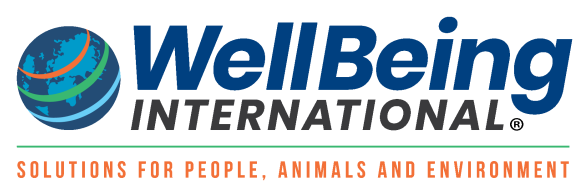




\title{
Social, Spacing, and Cooperative Behavior of the Collared Peccary, Tayassu tajacu
}

\author{
John A. Byers ${ }^{1}$ and Marc Bekoff ${ }^{2}$ \\ ${ }^{1}$ University of Idaho \\ ${ }^{2}$ University of Colorado
}

\begin{abstract}
$\underline{\text { ABSTRACT }}$
Social behavior of the collared peccary was studied on the lower, eastern slopes of the Mazatzal Mountains, Arizona. The social unit in this species is a cohesive herd, in which small inter-individual distances are maintained. Two conspicuous acts, one olfactory and one auditory, functioned to maintain close spacing. Social interactions were brief but tended to synchronize the activities of animals and also to bring them closer together. Amicable and neutral actions occurred far more frequently than agonistic interactions. Most agonistic behavior did not involve physical contact. Cooperative nursing, predator defense, and feeding occurred; all adults were tolerant of young, and males showed little overt competition over estrous females. The absence of sexual dimorphism, the 1:1 sex ratio within social groups, and the small, precocial litters in this species suggest an evolutionary history of pronounced sociality. Kin selection possibly was important in the evolution of social behavior in peccaries.
\end{abstract}

The Artiodactyla are an appropriate group for comparative study of social behavior because they occupy a wide variety of habitats and show a broad range of social organizations. Within the order, plains-living forms have been studied more than forest-dwellers, and members of the Bovidae have received more attention than other families. However, as Geist (1977) stated recently, important exceptiOJIS to generalizations from bovids may occur in the families Suidae and Tayassuidae. We report here data on social behavior and organization of the collared peccary, Tayassu tajacu, a small-bodied neotropical ungulate that, since the Pleistocene, has extended its range into North America.

In Arizona and Texas, where they have been studied most intensively, collared peccaries live almost exclusively in herds of about 5 to 15 individuals (Bigler, 1974; Bissonette, 1976; Ellisor and Hartwell, 1969; Jennings and Harris, 1953; Knipe, 1957; Minnamon, 1962; Neal, 1959; Schweinsburg, 1969, 1971; Sowls, 1974). The average herd size in the Tuscon and Tortolita Mountains, where most of these earlier studies were conducted, was 7.7. Bissonette (1976) reported a mean of 13.6 for 11 herds in Big Bend National Park, Texas. Enders (1930) and Leopold (1959) reported herd sizes in Panama and Mexico, respectively, that were comparable to those in Arizona. Miller (1930) reported an average size of 12 for herds in the Matto Grosso, Brazil. The average of "minimum group sizes" reported by Kiltie (1980) in the Manu National Park of Peru was 2.4, but he believed that group sizes were underestimated because of the difficulty of approaching and observing peccaries in a rainforest. 
Bigler (1974), Bissonette (1976), Schweinsburg (1971), and Sowls (1974) found adult sex ratios not significantly different from 1:1. Reported herd size and composition usually were stable throughout the year, herds foraged in tightly-knit groups, and animals rested together and slept side-by-side (Bigler, 1964; Bissonette, 1976; Ellisor and Hartwell, 1969; Knipe, 1957; Minnamon, 1962; Schweinsburg, 1971; Sowls, 1974).

No other artiodactyl, except perhaps the two other species of peccaries (Kiltie, 1980; Wetzel, 1977a), have such stable, mixed-sex groups. Sowls (1974) claimed that males did not compete vigorously for estrous females and that, "the need of individuals for the presence of others of their own species is strong." These statements and information about group composition suggested that $T$. tajacu might be a highly social species in which special mechanisms to promote group cohesion have evolved. High degrees of sociality, extending to various forms of cooperation and apparent altruism, seemingly are rare in the Mammalia, and species in which such behavior is shown merit special attention to obtain examples of ways in which the basic rule of individual selfishness (Wilson, 1975) has been circumvented. Therefore, we decided to obtain data on the rates at which amicable and agonistic behavior were performed, on spacing patterns, and on cooperative acts to determine if peccaries were as highly social as intimated in the literature.

\section{STUDY SITE AND METHODS}

\section{Study Site}

Collared peccaries were studied at the 3-Bar Wildlife Area, Tonto Basin, Arizona. The 3-Bar is a 155-km² preserve on the eastern slope of the Mazatzal Mountains; its western boundary is the ridge of the mountain range and its eastern boundary is the Theodore Roosevelt Reservoir. The area covers an elevation gradient from 700 to $2,200 \mathrm{~m}$, and contains vegetation communities that range from Sonoran desert scrub through diverse chapparal types to ponderosa pine (Pinus ponderosa). At lower elevations, where we studied peccaries, the northern half of the 3-Bar's topography consists of heavily dissected Precambrian granite. Rock Creek, the main drainage through this region, has cut a very steep-walled canyon in places; elsewhere, there are numerous washes that carve the land into a complex series of ridges. Wash bottoms are as much as $100 \mathrm{~m}$ below the ridges. Toward the south, the granite is overlaid by a younger sandstone (C. Byers, pers. comm.), which results in a more open, meadow-like terrain. The desert portion of the 3-Bar receives an average of about $35 \mathrm{~cm}$ of precipitation per year (R. Horejsi, pers. comm.), but large variation between years is common. Temperatures range between $-10^{\circ}$ and $+47^{\circ} \mathrm{C}(\mathrm{R}$. Horejsi, pers. comm.).

Peccaries were studied by the Arizona Game and Fish Department at the 3-Bar for about 15 years, and much detailed information on herd sizes, movements, home ranges, and feeding habits resulted from this work. Also, several experimental hunts of peccaries were conducted. In the northern half of the 3-Bar, where this study was concentrated, 84 animals from approximately five herds were killed in annual hunts between 1968 and 1975. No sanctioned hunting, and probably little illegal hunting has since occurred in the northern section of the 3-Bar. Cattle grazing was prohibited on the 3-Bar for about 30 years before our study.

Personnel of the Arizona Game and Fish Department placed a radio collar (collar transmitters and receiving equipment manufactured by Telonics, Inc., Mesa, Arizona) on one member of each herd they studied, and all herds we watched contained one, and sometimes two, radio-collared animals. These animals were captured with a Palmer Cap-Chur Gun loaded with a syringe containing 30 to $60 \mathrm{mg}$ of phencyclidine hydrochloride (Sernylan). Collared animals also were tagged with colored plastic ear tags. 


\section{Data Collection}

Observations were made at the 3-Bar between 13 September and 1 December 1978, 12 January and 1 June 1979, and 5 through 19 January 1980. During this time, $1,100 \mathrm{~h}$ were spent in the field, and peccaries were observed for $416 \mathrm{~h}$. Data were collected on seven different herds containing 57 adults and 23 juveniles. During the first 3 weeks of the study, an extensive behavioral repertoire was compiled.

Most adults were not tagged, and reliable identification of individuals was not possible. For most social interactions, determination of the sex of either animal also was not possible. An adult was identified as a male if its scrotum could be seen or if it played the male role in a complete copulation, and as a female if juveniles nursed from it, or if it played the female role in a complete copulation. Individual recognition of most juveniles was possible because of age-related size differences. Because most adult individuals could not be recognized and because animals drifted in and out of view, we decided to use ad lib. sampling (Altmann, 1974) as our primary method, although this technique may result in an overrepresentation of some individuals or of some kinds of behavioral acts (Altmann, 1974). However, other methods were either impractical, or would have greatly reduced the quantity of data collected.

Whenever possible, we positioned ourselves 70 to $90 \mathrm{~m}$ away from herds so that most individuals, and usually all those close enough to each other to interact, were within the field of view of the binoculars. We recorded our observations with a cassette tape recorder. In $416 \mathrm{~h}$ of observation, 1,293 social interactions, and 200 socially-related individual sequences of behavior, or $3.6(1,493 / 416)$ behavioral sequences per hour were recorded. We were confident that we recorded over $95 \%$ of all visible social interactions. An independent observer, present during approximately $100 \mathrm{~h}$ of data collection, confirmed this estimate.

The only category of behavior in which interactions and individual sequences of actions occurred too fast and too close together to record completely was play. Play tended to occur at specific sties, as a coordinated herd activity, and we could not record all the sequences of acts that occurred during these times. Therefore, the frequency of play motor patterns reported here is lower than the true frequency.

\section{Tests for Sampling Bias}

Nearest-neighbor data were used to test for differential visibility of individuals or age classes. At 20-min intervals, the age class and activity of each visible animal, its nearest neighbor, and the approximate distance between the two individuals were recorded. These data were used in sampling analyses to determine if some age classes or individuals were more visible than others. Three tests were made for differential visibility: 1) between adults and juveniles; 2) among age classes of juveniles; 3) among adults. In each test the G statistic (Sokal and Rohlf, 1969) was computed by use of expected frequencies based on proportional representation within the herd. We tested for differential visibility among adults (test 3 ) by comparing the frequencies with which radio-collared animals appeared in the nearest neighbor counts to the number of times they should have been counted based on their proportional representation in each herd. In the three $G$ tests, $P$, the probabilities that differences between observed and expected scores were a result of chance, were, respectively, $0.89,0.63$, and 0.91 . These findings and our confidence that over $95 \%$ of the visible social behavior (except play) was recorded, suggested that biases caused by sampling of certain individuals, age classes, or categories of behavior were unlikely. Also, because reliable identification of individuals other than radio-collared animals was not possible, social behavior likely was not preferentially sampled in some specific individuals in the infrequent instances that more than one interaction occurred at the same time. 


\section{The Behavioral Catalog}

We observed 9,245 behavioral acts, originally classified into 147 descriptive categories. In this detailed classification all perceptible differences between motor patterns were preserved; many acts were similar to others and all could be lumped into more general categories. However, 18 of these occurred with a frequency greater than $1 \%$ and together they accounted for $74.3 \%$ of all behavior observed. Nine patterns were observed only once; based on this, Good's estimate of coverage (Fagen and Goldman, 1977), a measure of the completeness of a behavioral catalog, was calculated to be 0.998 . We also fitted the frequency distribution of the 147 behavior patterns to a log-normal Poisson distribution (Fagen and Goldman, 1977), another method of estimating the completeness of an ethogram. The estimated repertory size by this method was $N=158.7$ (95\% confidence interval, \pm 15.3 ), and $\phi$, an estimate of the proportion of the true repertory described, was 0.926 .

For data analysis, the 147 motor patterns were grouped into 20 categories. In the following description, each category is listed and the percent of all behavior observed contributed by the category is shown. Beneath category headings the motor patterns each comprised are described; the percent of all behavior observed and the percent of behavior in the category contributed by each motor pattern are shown.

Approach (13.84\% of total).--Approach front, side (9.4\% of total; $58 \%$ of category): one animal walked toward another, so that its head approached the other's head, or side. Approach rear $(0.8 \%$ of total; $6.3 \%$ of category): one animal walked toward another so that its head approached the other's rump. Approach trot $(0.07 \%$ of total; $0.5 \%$ of category): this gait in peccaries resembled trotting in horses. Trotting was intermediate in speed between walking and running. Approach trot was scored if one animal approached another from any direction by use of this gait. Approach run $(0.63 \%$ of total; $4.6 \%$ of category): running was the fastest gait in peccaries. There was considerable dorsiflexion of the vertebral column. Approach run was scored if one animal approached another, from any direction, by use of this gait. Follow (2.9\% of total; $20.9 \%$ of category): one animal walked behind and followed the path taken by another. This pattern was scored only in the context of a social interaction and not when herds simply were moving.

Withdraw slowly (5.04\% of total).--Back up ( $0.51 \%$ of total; $8.0 \%$ of category): one animal, while facing its partner in a social interaction, backed away. The average distance traveled in Back ups was about $1.5 \mathrm{~m}$. This pattern occurred almost exclusively during interactions at a food source. Withdraw (4.67\% of total; $92 \%$ of category): one animal walked away from another during, or at the end of, a social interaction.

Withdraw fast ( $0.39 \%$ of total).--Withdraw trot $(0.39 \%$ of total; $33 \%$ of category): one animal trotted away from another during, or at the end of, a social interaction. Flee ( $0.26 \%$ of total; $67 \%$ of category): one animal ran away from another during, or at the end of, a social interaction.

Agonistic (4.8\% of total).--Bite ( $0.12 \%$ of total; $2.7 \%$ of category): one animal bit another. We had no way of judging the force that was applied, but we never observed bleeding or wounds to result. Brace $(0.08 \%$ of total; $1.8 \%$ of category): one animal, approached by another, assumed a hunched posture, with all four feet squarely planted, the head lowered and pulled back, and the ears laid back. Butt $(0.05 \%$ of total; $1.1 \%$ of category): one animal struck another with its snout or forehead. Fast head turn, mouth closed ( $0.2 \%$ of total, $4.3 \%$ of category): one animal rapidly swung its head toward a nearby individual; the mouth remained closed. Fast head turn, mouth open ( $0.5 \%$ of total; $10.6 \%$ of category): one animal rapidly swung its head toward a nearby individual; the mouth was open. When close to herds, we could hear that this pattern often was accompanied by a barking-type vocalization. Face $(0.45 \%$ of total; $9.4 \%$ of category): one animal, approached by or having approached another, stood with all four legs squarely planted, and the head held level. The head was not lowered, and the ears may or may not have been held back. Gape ( $0.18 \%$ of total; $4.0 \%$ of category): one animal, approached by or having approached 
another, widely opened its mouth, exposing its canines. The head was held level. We could not determine if the lips were retracted. Kneel $(0.09 \%$ of total; $2.0 \%$ of category): in a social interaction, one animal knelt on its carpal joints. Bissonette (1976) wrote that this is a submissive action that occurred during conflict at a food source; we agree. Lift with snout ( $0.03 \%$ of total; $0.7 \%$ of category): one animal placed its snout in the axilla or under the belly of another and violently jerked its head up. We saw this occur three times; in each instance, the recipient immediately rolled onto its back. Lower head $(0.05 \%$ of total; $1.1 \%$ of category): one animal lowered its head, as in the pattern Brace, but may have been walking, and did not have its weight evenly distributed over all four legs. Lunge $(0.23 \%$ of total; $4.7 \%$ of category): one animal left its forefeet to leap forward at another; the mouth was open. Push ( $0.18 \%$ of total; $3.8 \%$ of category): one animal shoved against another, usually with its shoulder, but sometimes with its head. Push down ( $0.03 \%$ of total; $0.7 \%$ of category): one animal applied pressure to another's back or upper shoulder or neck by use of its snout and forced the other into a reclining posture. Roll onto back $(0.06 \%$ of total; $1.3 \%$ of category): one animal reclined, rolled onto its back, and remained motionless in response to a Lift with snout or Push down by another animal. Recline $(0.10 \%$ of total; $1.4 \%$ of category): This pattern is described in another category, but it sometimes occurred (with the frequency listed) as a submissive action. One animal lay on its brisket, with its head stretched out straight in front, and its legs drawn beneath the body. Sink back ( $0.19 \%$ of total; $1.3 \%$ of category): one animal, usually in response to a Fast head tum, mouth open, by another, lowered its shoulders, kept its head level, and shifted most of its weight onto the hind legs, so that its forelegs were stretched out straight in front. This pattern resembled the play bow that Bekoff (1977) described in canids. Snap (0.14\% of total; $2.9 \%$ of category): one animal directed a rapid biting movement at another, but did not make contact. The canines usually were visible. Stand over ( $0.38 \%$ of total; $7.9 \%$ of category): one animal, in an agonistic interaction in which the recipient reclined or rolled onto its back, stood with its chin above the other's head, neck, or anterior trunk. During Stand overs, the recipient remained motionless. Tooth clack ( $0.03 \%$ of total; $0.7 \%$ of category): the sound began with a low-pitched, growling vocalization that gave way to an explosive series of "pops" or "clacks," made by rapid, orthal movements of the mandible. There was a distinct, hollow, "popping" component, similar to the sound one can make by pressing the tongue forcefully against the palate, then rapidly drawing it away. Snarl, growl ( $0.06 \%$ of total; $1.3 \%$ of category): the snarl or growl sounded similar to the so-named vocalization of dogs, but also there were easily audible differences difficult to describe verbally. Probably, this vocalization occurred much more frequently than noted. Most of the time, we were too far away from herds to detect anything other than loud sounds. Whirl $(0.41 \%$ of total; $8.5 \%$ of category): one animal rapidly spun to face another. Whirl, mouth open ( $0.22 \%$ of total; $4.9 \%$ of category): one animal whirled, with its mouth held open. Squabble (1.07\% of total; $22.2 \%$ of category): in a Squabble, both interactants faced each other, raised their snouts, opened their mouths, and emitted the Snarl or growl, while each moved its snout laterally back and forth about that of the other, usually making biting movements.

Courtship and copulation (2.75\% of total).--Chin on back ( $0.49 \%$ of total; $18 \%$ of category): one animal placed its chin on the back of another. Chin on head ( $0.04 \%$ of total; $1.6 \%$ of category): one animal placed its chin on the head of another. Chin on neck ( $0.35 \%$ of total; $12.5 \%$ of category): one animal placed its chin on the dorsal part of the neck of another. Chin on rump $(0.35 \%$ of total; $12.5 \%$ of category): one animal, standing directly behind and in line with another, placed its chin on the sacral region of the other's back, in the vicinity of the dorsal gland. Chin slide on back $(0.10 \%$ of total; $3.9 \%$ of category): one animal, standing perpendicular, or nearly so, to another, placed its chin on the dorsal part of the neck or on the back immediately posterior to the neck, and slid its chin posteriorly along the back, to the rump. Mount attempt ( $0.15 \%$ of total; $5.5 \%$ of category): one animal attempted unsuccessfully to mount another. This action was properly oriented but failed, usually because the recipient moved forward. Mount ( $0.62 \%$ of total; $22.3 \%$ of category): the hindfeet of the mounting animal remained on the ground; the forelegs were draped on either side of the recipient's back, and the chest and belly rested against the 
rump and posterior back of the recipient. Dismount ( $0.49 \%$ of total; $17.6 \%$ of category): the mounting animal dropped back to all fours. Dismounts were not caused by movements of the recipient. Mount, misdirected ( $0.04 \%$ of total; $1.6 \%$ of category): one animal mounted another but not from the rear. Pelvic thrusts ( $0.15 \%$ of total; $5.5 \%$ of category): one animal, while mounted, vigorously rocked its pelvis forward and backward, at a rate of about once per s.

Play (13.61\% of total).--Play chase ( $0.12 \%$ of total; $0.95 \%$ of category): one animal ran to follow another running animal during a play bout. The roles of the two animals frequently were reversed. Play chase in circle $(0.64 \%$ of total; $4.7 \%$ of category): one animal ran to follow another running animal as both described a tight circle with a diameter of 1 to $2 \mathrm{~m}$. Dash (3.99\% of total; $29.2 \%$ of category): from a standing start, or following a Fast tum, one animal ran at high speed, in a relatively straight line, until it stopped, or executed another Fast turn. Dash in circle ( $0.42 \%$ of total; $3.1 \%$ of category): one animal, from a standing start, or following a Fast turn, ran at high speed in a tight circle. Fast turn $(0.89 \%$ of total; $6.58 \%$ of category): one animal, while running in play, abruptly changed direction by at least $90^{\circ}$. Frequently, the change in direction was close to $180^{\circ}$. Flip down $(0.07 \%$ of total; $0.55 \%$ of category): one animal, while Play-squabbling with another, grasped the other's lower jaw and twisted its head, throwing the recipient onto its side. There was no indication that the initiator had to wrestle the recipient to the ground, rather, the initiator lightly twisted its head, and the recipient immediately fell onto its side. Flop ( $1.03 \%$ of total; $7.53 \%$ of category): one animal, interacting with another in play, threw itself onto its side. This action was not caused by contact with the other animal. Head toss $(0.45 \%$ of total; $3.33 \%$ of category): one animal opened its mouth slightly, and rapidly threw its head from a horizontal to a nearly vertical position, then back again to the horizontal. This happened once or several times in rapid succession. Leap $(0.03 \%$ of total; $0.24 \%$ of category): one animal jumped vertically into the air. No horizontal distance was traversed. Open mouth $(0.28 \%$ of total; $2.06 \%$ of category): one animal opened its mouth slightly, as in the Head toss. We saw this behavior pattern only in play. Paw other animal ( $0.01 \%$ of total; $0.08 \%$ of category): one animal approached a reclined animal, and solicited play by pawing at the other's side with a forefoot. Play dashing ( $0.10 \%$ of total; $0.71 \%$ of category). Play, general ( $0.16 \%$ of total; $1.18 \%$ of category): on a few occasions, we could not record the complete sequence of play motor patterns that occurred, but recorded the performance and duration of general types of play. Play dashing was recorded when one animal repeatedly dashed back and forth, each dash separated from others by a stop, or a Fast turn. General play was recorded when animals performed a variety of play motor patterns in addition to dashing. Play snap ( $0.16 \%$ of total; $1.1 \%$ of category): during play, one animal Snapped at another. The motor pattern was indistinguishable from the agonistic Snap, but in play it always was preceded and followed by a play pattern. Tumble $(0.06 \%$ of total; $0.47 \%$ of category): while interacting with another animal in play, one animal, from a standing position, tucked its head and performed a forward roll, landing on its back. Twice the tumbling animal ran downhill at the recipient, each animal grasped the other's lower jaw, and the initiator's momentum caused it to rotate in an arc above the recipient until it landed heavily on the downhill side. Play squabble (4.64\% of total; $33.91 \%$ of category): this pattern was similar in appearance to the Squabble in agonistic behavior. However, Play squabbling never was accompanied by the growling vocalization of its agonistic counterpart, and it always was preceded and followed by another play pattern. Roll onto back $(0.12 \%$ of total; $0.87 \%$ of category): a reclined animal, approached by a playing animal, rolled onto its back and often wiggled its legs in the air. Roll onto side $(0.13 \%$ of total; $0.95 \%$ of category): a reclined animal approached by a playing animal, rolled onto its side, and often displayed the Open mouth.

Mutual rub and related acts. (11.89\% of total).--Cut off ( $0.14 \%$ of total; $1.18 \%$ of category): one animal walked perpendicularly in front of another walking animal, causing the recipient to stop; the initiator then turned and Moved parallel. Move parallel (3.28\% of total; $28.29 \%$ of category): one animal, after approaching another or following a Cut off, moved so that it was side-to-side with the other, in a head-to- 
tail orientation. Mutual rubs usually, but not always, followed. Mutual rub (7.66\% of total; $64.10 \%$ of category): two animals, oriented head-to-tail with their sides touching simultaneously rubbed the sides of their heads up and down over the other's rump in the region of the dorsal gland. Both animals usually started and stopped at about the same time. Perpendicular mutual rub $(0.05 \%$ of total; $0.45 \%$ of category): one animal, standing behind and perpendicular to another, rubbed its cheek in Mutual rub fashion over the other's rump in the region of the dorsal gland. Unreciprocated mutual rub $(0.71 \%$ of total; $5.98 \%$ of category): one animal, in the typical Mutual rub posture with another, Mutual rubbed, while the other stood without moving.

Scent marking (2.88\% of total).--Dorsal gland mark ( $0.45 \%$ of total; $16.09 \%$ of category): one animal rubbed its dorsal gland against an object, or stood close and squirted dorsal gland material onto the object, or squatted, and rubbed the gland on the ground. Erect dorsal bristles $(0.08 \%$ of total; $3.07 \%$ of category): one animal elevated its dorsal bristles, especially in the vicinity of the dorsal gland. This pattern was scored only in the context of other scent-marking activities, and not when animals were alarmed. Erect dorsal bristles and shake (1.52\% of total; $54.41 \%$ of category): one animal elevated its dorsal bristles and shook vigorously. This usually occurred during other scent-marking activities and was distinct from simple comfort-movement shaking because the dorsal bristles were erected conspicuously. Defecate $(0.25 \%$ of total; $8.81 \%$ of category): acts scored in this category referred to defecation that occurred as a coordinated herd activity, closely associated with other kinds of scent marking. Paw ground ( $0.28 \%$ of total; $9.96 \%$ of category): one animal repeatedly pawed one spot with a forefoot. Rub head on ground ( $0.04 \%$ of total; $1.53 \%$ of category): one animal, after investigating a scent-marked area, fell onto its side and rubbed the side of its head back and forth on the ground. Thrash $(0.08 \%$ of total; $2.68 \%$ of category): one animal, after investigating a scent-marked area, fell onto its side and wiggled, squirmed, and jerked about vigorously. Urinate ( $0.10 \%$ of total; $3.45 \%$ of category): one animal urinated and either preceded or followed this with another form of scent marking.

Olfactory investigation and contact (4.93\% of total).--Grouped under this heading were 30 acts, most of which were examples of the same act (lick, nose, or nuzzle) applied to different regions of the body of the recipient. Lick (see specific area licked): one animal licked another. Lick back $(0.03 \%$ of total; $0.65 \%$ of category); Lick dorsal gland $(0.01 \%$ of total; $0.15 \%$ of category); Lick ear $(0.04 \%$ of total; $0.86 \%$ of category); Lick face ( $0.13 \%$ of total; $2.81 \%$ of category); Lick neck ( $0.01 \%$ of total; $0.15 \%$ of category); Lick, general ( $0.04 \%$ of total; $0.85 \%$ of category); one animal licked an area not specified above. Lift hind leg $(0.03 \%$ of total; $0.64 \%$ of category): an animal reclined on its side, lifted a hind leg so that another could Nose its belly and inguinal region. Nibble ear ( $0.08 \%$ of total; $1.73 \%$ of category): one animal gently mouthed another's ear. Nose (see specific area nosed): one animal applied its nose to, or close to, another. Sniffing, or movements of the rhinal disk were sometimes seen. Nose belly $(0.03 \%$ of total; $0.64 \%$ of category); Nose dorsal gland ( $0.69 \%$ of total; $13.85 \%$ of category); Nose ear ( $0.24 \%$ of total; $4.97 \%$ of category); Nose eye ( $0.09 \%$ of total; $1.94 \%$ of category); Nose face $(0.10 \%$ of total; $2.16 \%$ of category); Nose mouth $(0.05 \%$ of total; $1.08 \%$ of category); Nose neck $(0.03 \%$ of total; $0.64 \%$ of category); Nose nose (1.01\% of total; $20.34 \%$ of category) (This was a mutual act, in which both animals stretched their necks forward and brought their rhinal disks close together, sometimes lightly touching); Nose perineum $(0.73 \%$ of total; $14.72 \%$ of category); Nose side ( $0.14 \%$ of total; $2.81 \%$ of category). Nuzzle (see specific area nuzzled): one animal touched another with its nose, then moved the nose gently up and down, or from side to side. The initiator's mouth was occasionally slightly open. Nuzzle belly $(0.02 \%$ of total; $0.43 \%$ of category); Nuzzle dorsal gland $(0.06 \%$ of total; $1.30 \%$ of category); Nuzzle ear $(0.20 \%$ of total; $4.11 \%$ of category); Nuzzle head $(0.12 \%$ of total; $2.38 \%$ of category); Nuzzle mouth ( $0.05 \%$ of total; $1.08 \%$ of category); Nuzzle neck ( $0.15 \%$ of total; $3.03 \%$ of category); Nuzzle perineum ( $0.14 \%$ of total; $2.81 \%$ of category); Nuzzle shoulder ( $0.05 \%$ of total; $1.08 \%$ of category); Nuzzle side $(0.05 \%$ of total; $0.86 \%$ of category); Nuzzle, general $(0.19 \%$ of total; $3.90 \%$ of category); one animal 
nuzzled another in an area not already specified. Rub cheeks ( $0.23 \%$ of total; $4.54 \%$ of category): this was a mutual activity in which both animals, facing each other, rubbed the sides of their heads and faces together.

FIG. 1. Cumulative frequency distribution for the duration of 1,293 social interactions between collared peccaries, central Arizona, 1978-1980.

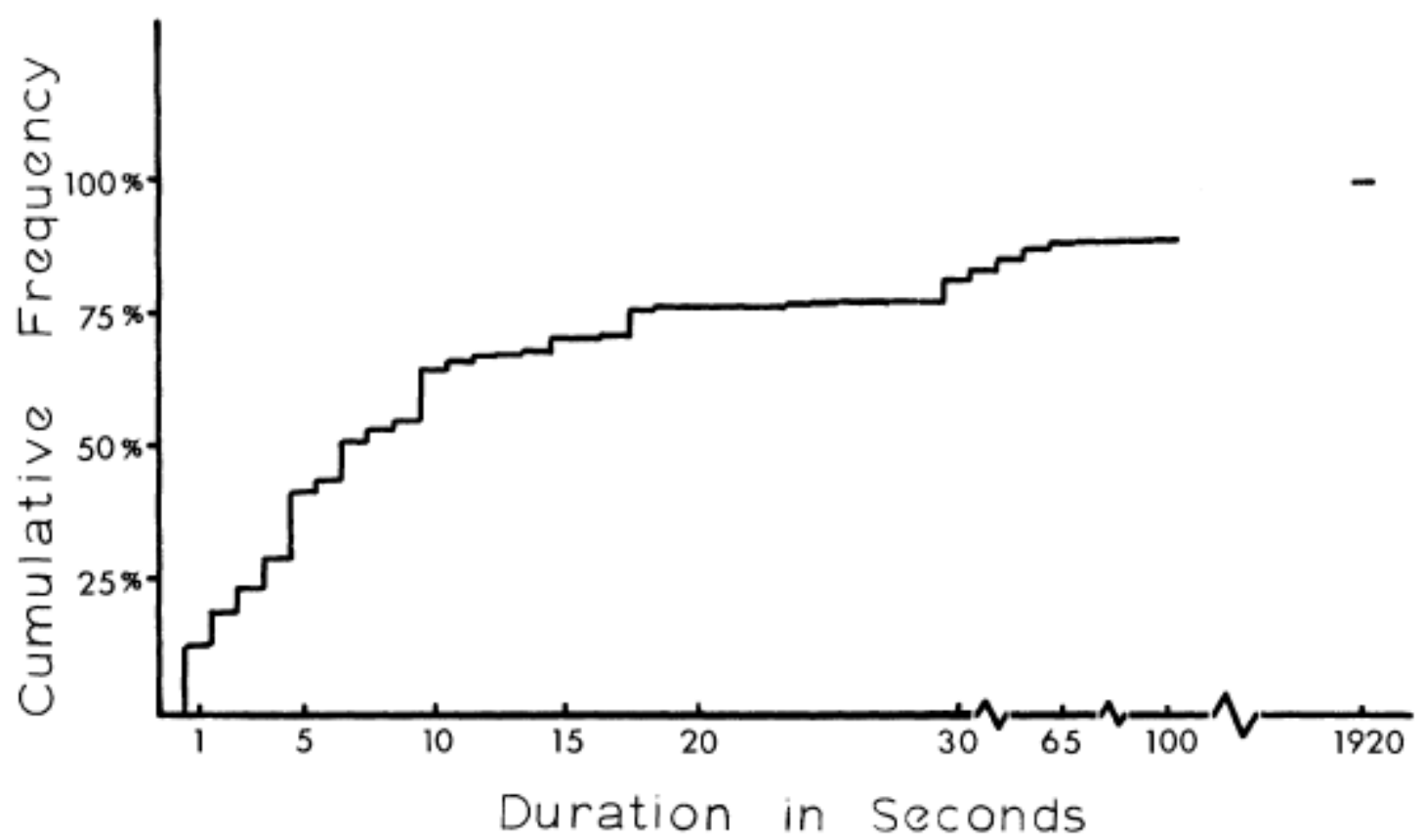

Olfactory investigation of environmental stimuli ( $0.67 \%$ of total). -Nose ground ( $0.27 \%$ of total; $40.32 \%$ of category): one animal, while standing and not feeding, applied its nose to the ground while moving the rhinal disk. We were too far away, in instances in which we recorded this pattern, to determine what the animal investigated. Nose marked object ( $0.35 \%$ of total; $51.61 \%$ of category): one animal applied its nose to the ground or to an object that was the site of previous dorsal gland mark. Nose urine $(0.05 \%$ of total; $8.06 \%$ of category): one animal applied its nose to the ground at a spot where we had seen another peccary urinate shortly before.

Close feeding (2.37\% of total).--Feed, mouth to mouth (2.36\% of total; $99.54 \%$ of category): one animal approached another feeding individual, and fed from the same food source, its mouth touching or almost touching that of the other. Feed under ( $0.01 \%$ of total; $0.46 \%$ of category): a juvenile walked beneath a feeding adult, and fed there.

Other amicable contact (1.98\% of total).--Recline (1.11\% of total; $50.24 \%$ of category): one animal approached another reclined individual and lay down next to it. Peccaries most frequently reclined by first kneeling on their carpal joints, then lowering their hind quarters. Recline touching $(0.25 \%$ of total; $10.73 \%$ of category): one animal approached another reclined individual, and lay down, touching the recipient. Walk parallel ( $0.53 \%$ of total; $23.90 \%$ of category): one animal approached another walking individual and walked side by side with it, often with its shoulder touching that of the other animal. Walk under $(0.07 \%$ of total; $7.80 \%$ of category): a juvenile approached and walked under a standing adult. Squabble, gentle ( $0.16 \%$ of total; $7.32 \%$ of category): this was a mutual action in which both animals assumed postures similar to the agonistic Squabble, but moved their heads much more slowly, usually had their mouths less 
open, and did not vocalize. We distinguished it from the play squabble because of its curious, slowmotion quality, and because it did not occur during play bouts.

FIG. 2. Frequency distribution for the number of acts performed per animal per interaction in 1,293 social interactions between collared peccaries, central Arizona', 1978-1980.

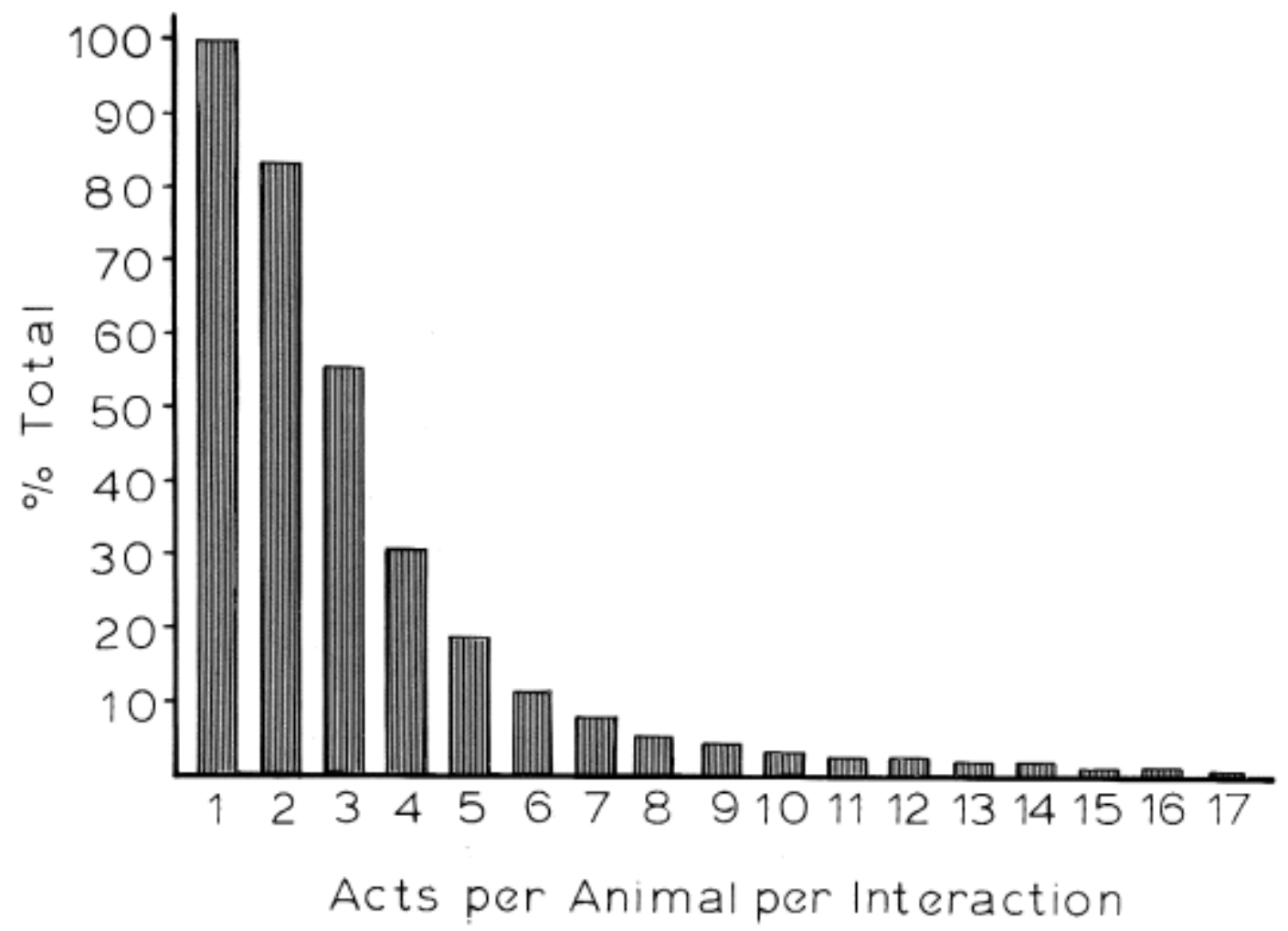

Feed (6.07\% of total).--Behavior in this category was scored only when feeding took place during, at the beginning, or at the end of a social interaction. Feed (6.91\% of total; $98.30 \%$ of category): one animal fed as another approached, withdrew, or directed any social act at it, or one animal fed near another after approaching it. We scored interactions in which the recipient continued to feed, and the initiator approached, then fed, only when the initiator approached to within $1 \mathrm{~m}$ or less of the recipient. Paw food ( $0.01 \%$ of total; $0.15 \%$ of category): one animal pawed at a food item during a social interaction. Root ( $0.11 \%$ of total; $1.54 \%$ of category): one animal used its rhinal disk to move earth or plant material during a social interaction.

Passing related actions ( $0.39 \%$ of total).--Peccaries occasionally competed over a more forward position in line during herd movements, or sometimes, to be ahead of each other when the herd was fanned out, feeding. The function of this activity was not clear. Pass ( $0.16 \%$ of total; $40.50 \%$ of category): one animal accelerated its pace and passed another. Pass attempt ( $0.14 \%$ of total; $35.13 \%$ of category): one animal attempted unsuccessfully to pass another. The other possibly responded with a Fast head turn or simply increased its speed to avoid being passed. Move faster in pass attempt $(0.05 \%$ of total; $13.51 \%$ of category): both animals during a passing competition, began to walk fast, then trot, and sometimes even ran, until one succeeded in passing. Give up, follow ( $0.04 \%$ of total; $10.81 \%$ of category): one animal, during a passing competition, abruptly slowed down or stopped, allowing the other to pass, then resumed walking behind the animal that had passed it. 
Locomote (3.50\% of total).--One animal performed one of the three types of locomotion listed during a social interaction, but did not withdraw from the individual with which it interacted. Walk (3.17\% of total; $90.5 \%$ of category). Trot ( $0.11 \%$ of total; $3.19 \%$ of category). Run $(0.22 \%$ of total; $6.4 \%$ of category).

FIG. 3. Frequencies with which social interactions between collared peccaries (central Arizona, 1978-1980) resulted in the interactants being closer together, further apart, no closer nor no further, or closer briefly, then further apart. The distribution was significantly nonrandom (G=850.7, d.f. $=3, P<0.001)$.

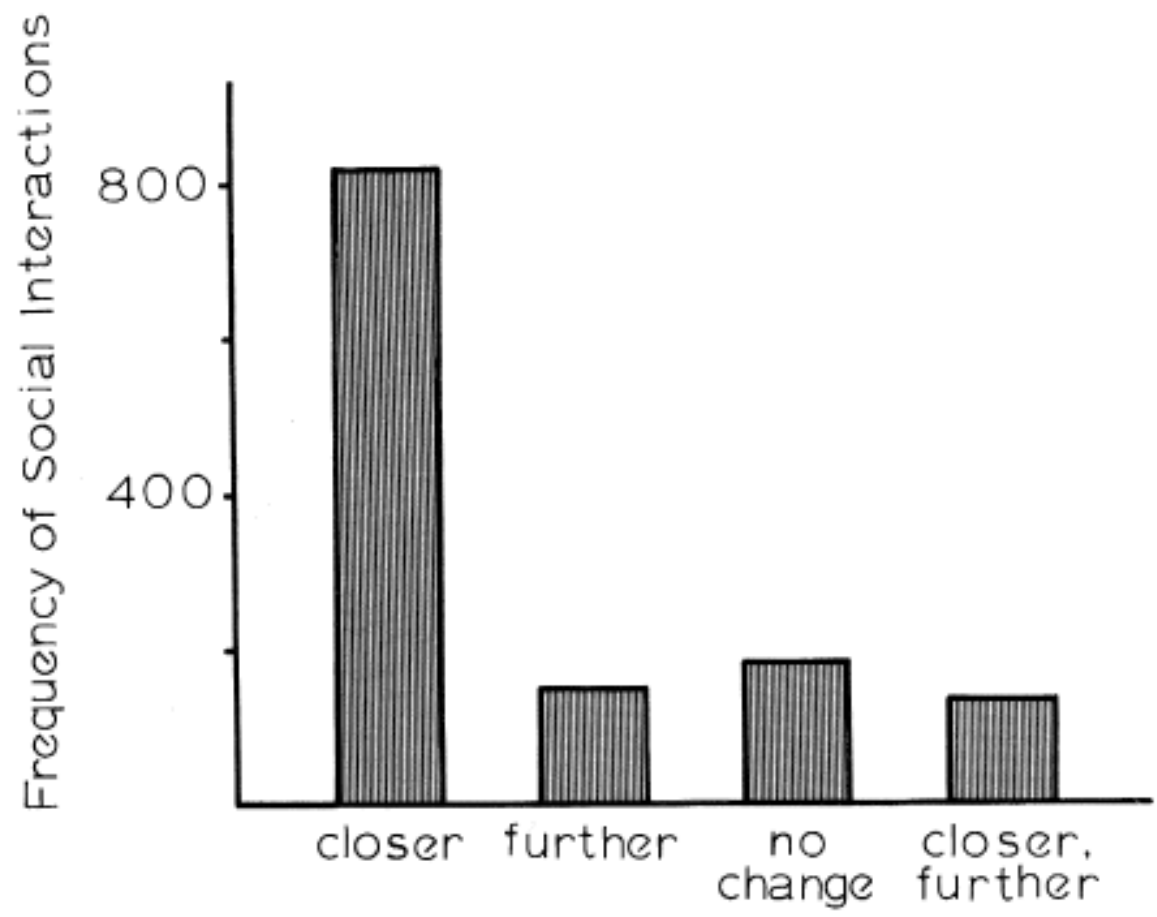

Change in Distance Between Interactants

Comfort movement $(0.22 \%$ of total).--Scratch self ( $0.01 \%$ of total; $5.0 \%$ of category): one animal, while standing, scratched its shoulder, neck, or ear with a hind hoof. Shake $(0.06 \%$ of total; $30 \%$ of category): one animal, while standing, shook itself vigorously, so that its bristles swung from side to side. The dorsal bristles were not erected. Stretch ( $0.03 \%$ of total; $15.0 \%$ of category): one animal shortly after getting up, moved its forefeet far forward, while leaving its hindfeet in place, so that its vertebral column was stretched and slightly bowed ventrally. The animal then usually walked a few paces with its forefeet, allowing the anterior sides of the hind hooves to drag about $1 \mathrm{~m}$, before it walked normally. Yawn $(0.10 \%$ of total; $0.50 \%$ of category): yawns differed from Gapes in the contexts in which they occurred and in the speed with which they were performed. Yawns were performed only by bedded animals or by animals that had just risen. The mouth was opened and closed in a smooth motion. In the Gape the mouth was help open for several seconds.

Neutral activity (18.55\% of total).--Do nothing (3.28\% of total; $17.6 \%$ of category): a reclined animal approached by another, showed no visible response. Interact with other $(0.49 \%$ of total; $2.67 \%$ of category): one animal, approached by, or the recipient of a social act by another, interacted with a third individual. Stand ( $14.86 \%$ of total; $79.71 \%$ of category): a standing, walking, or feeding animal, approached by, or the recipient of a social act by another, stood without moving, with its head held level. 
Nursing (2.39\% of total).--Nurse (2.18\% of total; $90.54 \%$ of category): a juvenile, after approaching an adult female (almost always from behind), suckled while the female stood. Nurse attempt $(0.23 \%$ of total; $9.46 \%$ of category): a juvenile, after approaching an adult, attempted to suckle, but the adult withdrew.

Position related changes (2.63\% of total).--Get up (1.35\% of total; $52.97 \%$ of category): a reclined animal, approached by another, stood up. Stand behind ( $0.06 \%$ of total; $2.54 \%$ of category): during a social interaction, one animal moved to stand behind another. Stand parallel $(0.42 \%$ of total; $16.52 \%$ of category): during a social interaction, one animal moved to stand side-by-side with the other, in a head-tohead position. Stand perpendicular ( $0.05 \%$ of total; $2.12 \%$ of category): during a social interaction, one animal moved to stand in front of, and perpendicular to, the other. Stand under $(0.08 \%$ of total; $2.99 \%$ of category): a juvenile moved to stand underneath an adult. Turn head away $(0.03 \%$ of total; $1.27 \%$ of category): during a social interaction, one animal turned its head to face away from the other. Turn head toward $(0.04 \%$ of total; $1.69 \%$ of category): during a social interaction, one animal turned its head to point toward the other. Turn away ( $0.18 \%$ of total; $7.20 \%$ of category): during a social interaction, one animal turned to orient its body away from the other. Turn toward ( $0.32 \%$ of total; $12.71 \%$ of category): during a social interaction, one animal turned to orient its body with its head pointing toward the other.

TABLE 1. Rates at which social acts of collared peccaries occurred during different herd activities, central Arizona, 1978-1980. Rate $=$ frequency of motor patterns $\mathrm{h}^{-1}$ animal ${ }^{-1}$.

\begin{tabular}{|lc|}
\hline Herd activity & Rate of social behavior \\
\hline Moving & 11.18 \\
Moving in line & 2.04 \\
Feeding & 1.18 \\
Bedded & 2.87 \\
Entering bedground & 39.52 \\
Leaving bedground & 6.81 \\
Alarmed & 14.20 \\
Playing & 21.63 \\
\hline
\end{tabular}

Vocalizations $(0.30 \%$ of total).--Peccaries vocalized much more than suggested by the calculated frequency. We recorded only vocalizations that occurred during, or resulted in, a social interaction. Bark ( $0.06 \%$ of total; $17.85 \%$ of category): this vocalization sounded similar to the bark of a dog. Distress call ( $0.22 \%$ of total; $71.43 \%$ of category): adults and juveniles both gave this vocalization when they became separated from their herds. In juveniles, the sound was a loud, high-pitched squalling, similar to the cry of a human infant. In adults, the vocalization seemed to have the same temporal pattern, but was lower pitched. Low grunt $(0.03 \%$ of total; $10.71 \%$ of category): peccaries low grunted frequently, but rarely that we heard, during a social interaction. The vocalization was a repetitive, low-pitched, flat sound with an apparently sharp onset and an approximate duration of $1 / 4$ to $1 / 2 \mathrm{~S}$.

\section{RESULTS}

Social behavior.--Most social interactions were brief. A few that involved play or courtship were long, but over half of all interactions lasted no longer than $7 \mathrm{~s}$ (Fig. 1). Also, most encounters involved six or fewer acts performed by each animal (Fig. 2).

After social interactions, both the initiator and the recipient usually continued to perform the activity (recline, stand, walk, feed, or play) in which they were engaged before the interaction began (initiator, $\mathrm{G}=$ 223.2, d.f. $=1, P<0.001$; recipient, $G=242.8$, d.f. $=1, P<0.001$ ). However, when an animal changed its 
activity as a result of a social interaction, it tended to be in favor of mimicking the activity of the other animal; before interactions, the activities of interactants were the same $59 \%$ of the time and after interactions were the same $75 \%$ of the time $\left(X^{2}=82.6\right.$, d.f. $\left.=1, P<0.001\right)$. In most instances, social interactions also resulted in a decrease in distance between animals (Fig. 3 ).

Social behavior occurred at high rates while herds were entering bedgrounds, playing ( $72 \%$ of play occurred as herds were entering bedgrounds), alarmed, or moving, and at low rates when herds were feeding, moving in a line, bedded, or leaving a bedground (Table 1).

Most peccary behavior patterns observed were amicable or neutral activities (Figs. 4, 5, and 6). The amicable patterns involved in play, mutual rubbing, and olfactory investigation and contact dominated social acts recorded (Fig. 4). The essentially neutral acts, such as stand, do nothing, and approach, constituted the bulk of position-related acts (Fig. 5), and feeding, another neutral activity, constituted the bulk of all individually-oriented acts (Fig. 6).

Spacing.--Bigler (1974), Bissonette (1976), Ellisor and Hartwell (1969), Jennings and Harris (1953), Minnamon (1962), Neal (1959), Schweinsburg (1971), and Sowls (1974) provided general descriptions of daily activity patterns of peccaries. In the American Southwest, peccaries are primarily nocturnal in the summer and diurnal in the winter (Bissonette, 1978). These shifts are likely related to temperature regulation. In winter, peccaries probably must huddle together at night to maintain body temperature; they forage and bask during the day. In summer, peccaries forage almost exclusively at night, and spend the entire day resting in a shaded bedground.

FIG. 4. Frequency distribution (frequencies expressed as percentages of 9,245 behavioral acts) for social acts performed by collared peccaries, central Arizona, 1978-1980. Abbreviations: mut. rub = mutual rub and related acts; olfac. cont. $=$ olfactory investigation and contact; other amic. cont. $=$ other amicable contact.

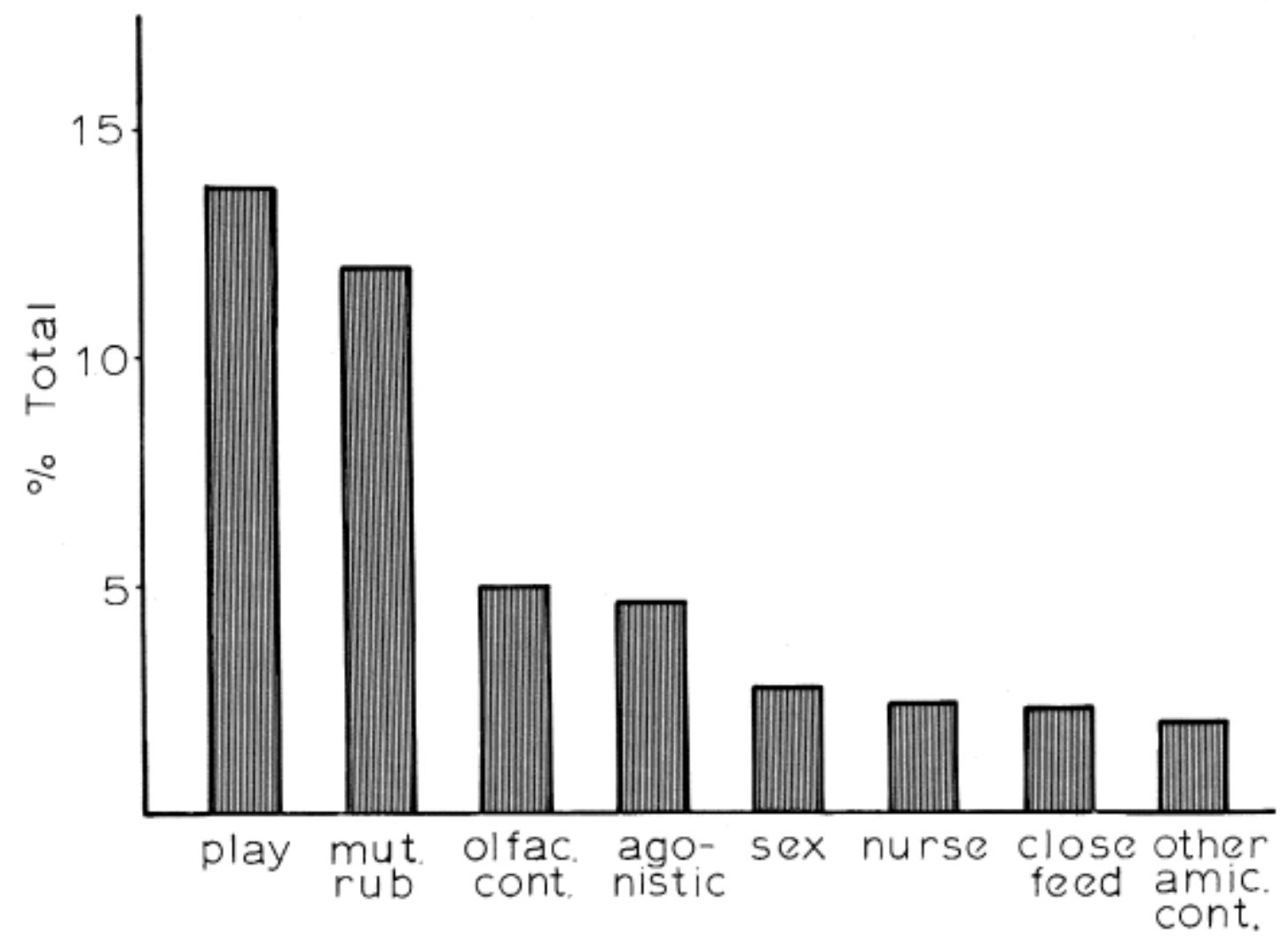


Herds almost always acted as a coordinated unit, entering and leaving bedgrounds, foraging, and moving en masse. The average nearest-neighbor distance for adults was $3.9 \mathrm{~m}$ with a $95 \%$ confidence interval of $3.8 \mathrm{~m}$. We estimated that from a standing start or a walk, peccaries probably could attain a top speed of about $3 \mathrm{~m} / \mathrm{s}$ over the first $5 \mathrm{~m}$, and somewhat greater speeds thereafter. Therefore, in terms of time, each adult was $3.9 \mathrm{~m} / 3 \mathrm{~m} \mathrm{~s}^{-1}$, or $1.3 \mathrm{~s}$, on the average (95\% of the time between 0.1 and $2.6 \mathrm{~s}$ ), away from its nearest neighbor. Peccaries performed two conspicuous acts, mutual rub and low grunt, which seemed designed to maintain small interanimal distances.

We hypothesized that individual peccaries, with their notoriously poor eyesight and keen sense of smell (Knipe, 1957; Schweinsburg, 1969), relied strongly on olfaction to determine their spatial position with respect to the rest of the herd. We hypothesized further that the function of the mutual rub was to aid this process, by smearing dorsal gland material over the heads and backs of the rubbing participants. If mutual rubbing functioned to promote group cohesion by making animals more effective broadcasters of dorsal gland scent, the act would be expected to occur most frequently just before or during times when it would be difficult or advantageous for individuals to remain close together; this was indeed the situation (Table 2). Peccaries mutual rubbed at a low rate at times during which herds were moving in a line on a trail, feeding, bedded, or playing, but mutual rubbed at a high rate during moving (not on a trail), leaving a bedground (to begin feeding), and, especially, when herds were alarmed.

FIG. 5. Frequency distribution (frequencies expressed as percentages of 9,245 behavioral acts) for positionrelated acts performed by collared peccaries, central Arizona, 1978-1980. Abbreviations: aprch = approach; wd slow $=$ withdraw slowly; change position $=$ position related changes; wd fast $=$ withdraw fast; pass = passing related actions.

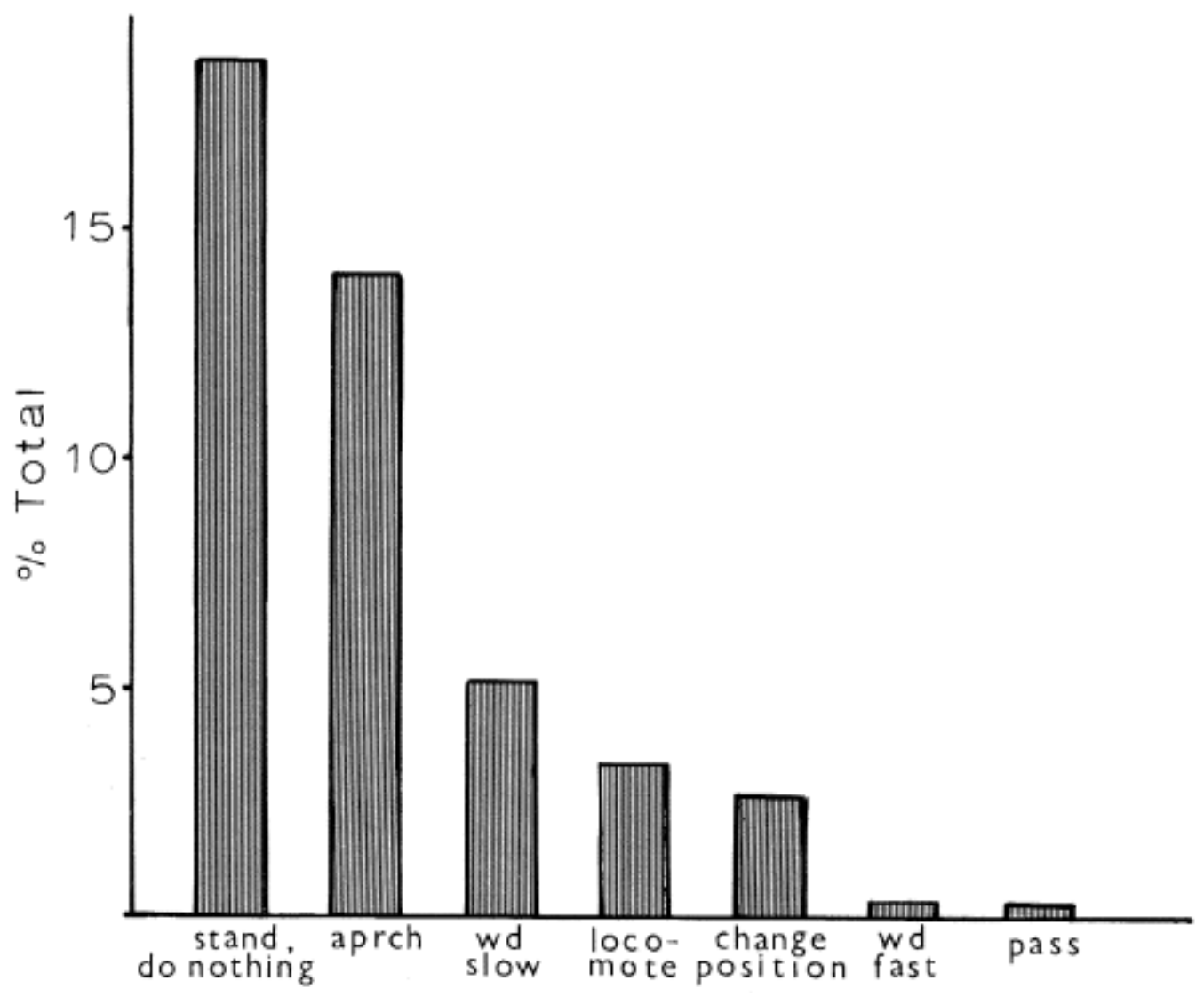


The low grunt also seemed to function to maintain close spacing. Often we were too far from herds to hear this flat, low-pitched sound, but in 40 instances in which we heard sustained (1 min or longer) low grunting we recorded the herd's activity. In 34 instances, the vocalization occurred during times when the maintenance of herd cohesion was most difficult or important; the herd was moving quickly, leaving a bedground, or reassembling after alarm. In six instances, the herd was feeding. Also, on four occasions low grunting was made by adults that were approaching a lost, distress-calling juvenile. Each time, the juvenile stopped calling and moved toward the adult. Finally, G. Day of the Arizona Game and Fish Department showed us that alarmed animals sometimes could be attracted by a good imitation of a low grunt.

Herds showed a strong tendency to remain together when peccaries were alarmed. Herds scattered in only 4 of 31 observed alarm situations. Individuals also showed signs of great distress when they became separated from herds. They ran back and forth, low grunted and, if not successful at finding the herd, began to utter loud squalling cries.

Cooperative behavior. In addition to the high level of amicable and cohesive behavior already described, peccaries also demonstrated active cooperation and apparent altruism.

FIG. 6. Frequency distribution (frequencies expressed as percentages of 9,245 behavioral acts) for individually oriented acts performed by collared peccaries, central Arizona, 1978-1980. Abbreviations: olfact environ = olfactory investigation of environmental stimuli; vocal = vocalizations.

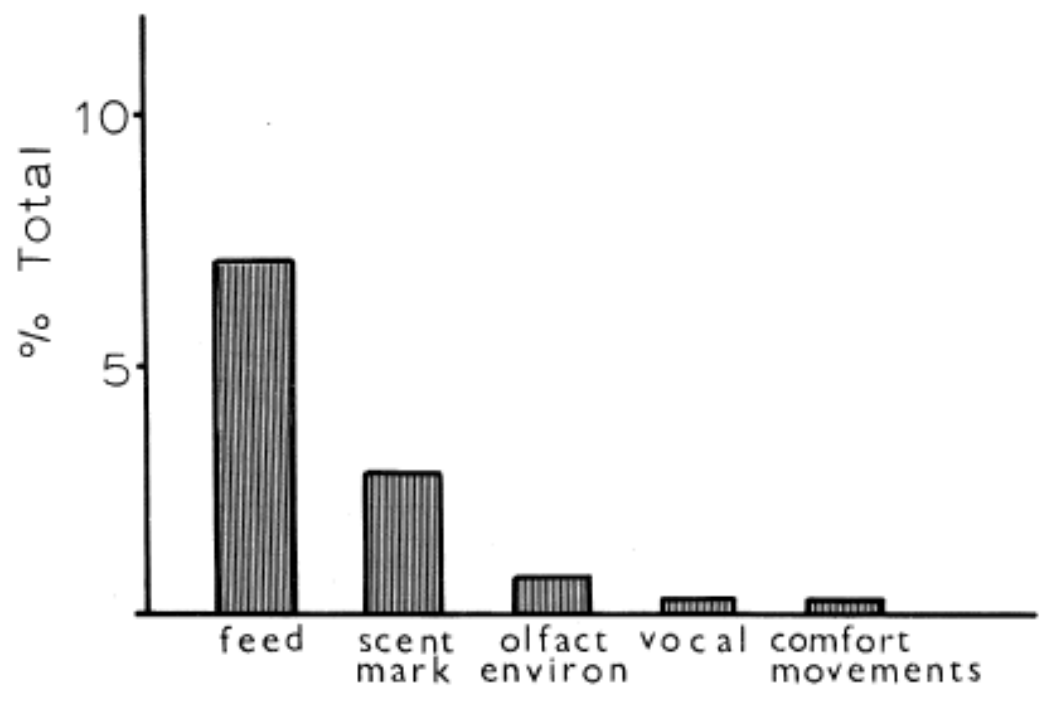

All herd members were tolerant of juveniles, and allowed them liberties that were not extended to other adults. When herds were bedded, juveniles often clambered on top of adults and sought to wedge themselves between them. Until about 5 months of age, juveniles also were able to approach feeding adults and feed mouth to mouth with them, and sometimes actually snatched food from the adults' mouths or aggressively drove them away. Adults almost never responded aggressively (Fig. 7). On three occasions, juveniles attempted to shoulder adults aside in a passing attempt; the adults simply allowed the juveniles to pass. Finally, in a typical adult-juvenile interaction, two 2-week-old animals stood beneath and snapped repeatedly at the mouth of a feeding adult. The adult was forced to raise its head to chew, and as it walked forward in this position, the juveniles walked beneath it, and caused it to stumble. There was no hostility. 
TABLE 2. Contexts in which mutual rubbing between collared peccaries occurred, central Arizona, 19781980. Rate $=$ frequency of motor patterns $h^{-1}$, animal $^{-1}$.

\begin{tabular}{|lccccccc|}
\hline Herd activity* & Moving & $\begin{array}{c}\text { Moving } \\
\text { in line }\end{array}$ & Feeding & Bedded $\begin{array}{c}\text { Leaving } \\
\text { bedground }\end{array}$ & $\begin{array}{c}\text { Entering } \\
\text { bedground }\end{array}$ & $\begin{array}{c}\text { Alarmed } \\
\text { Playing }\end{array}$ \\
\hline $\begin{array}{l}\text { Frequency of mutual rubs and related } \\
\text { actions }\end{array}$ & 77 & 6 & 723 & 43 & 123 & 37 \\
$\begin{array}{l}\text { Expected frequency } \\
\text { Rate }\end{array}$ & 8.7 & 2.2 & $1,005.6$ & 47.0 & 14.2 & 68 & 16 \\
\hline
\end{tabular}

* The distribution across herd activities was nonrandom: $G=1,023.1$, d.f. $=7, P<0.001$.

FIG. 7. The frequencies with which feeding interactions among adult and juvenile collared peccaries (central Arizona, 1978-1980) were agonistic or nonagonistic. "Approach" implies one animal moving to within $1 \mathrm{~m}$ of another feeding individual and beginning to feed. When juveniles approached adults, the outcome usually was nonagonistic $(Z=6.72, P<0.001)$.

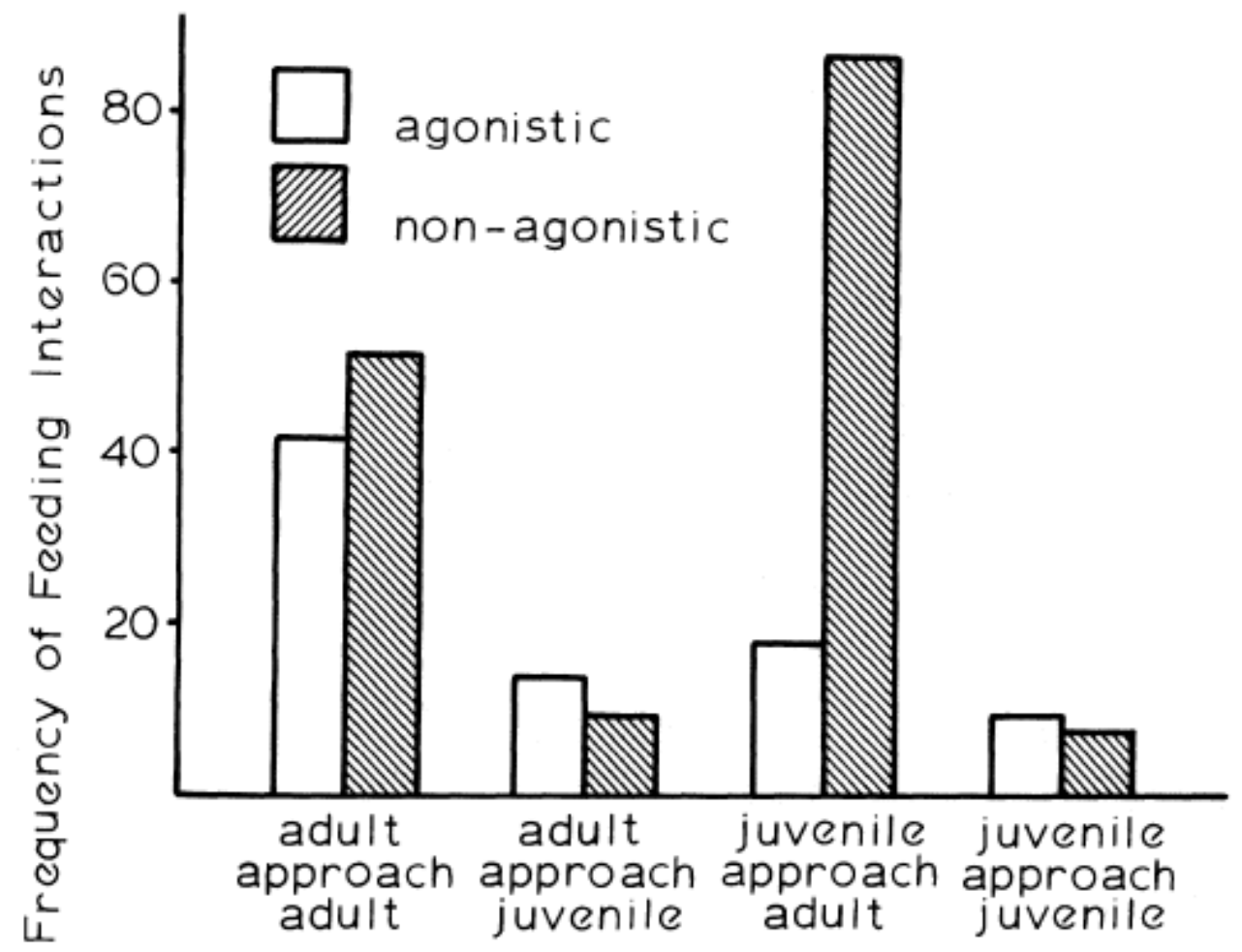

Peccary infants nursed from the rear while the females stood. Adult females made no discernable attempt to determine the identities of juveniles that nursed from them; this suggested that females may have given milk to juveniles other than their own. Nursing of other females' young was reported for captive collared peccaries by Frädrich (1967) and we found it to occur in the wild. Because most individuals could not be recognized, the rate at which cross-nursing occurred was not determined, but 32 instances in which a juvenile nursed from one female, then from another, were seen. We observed cross-nursing in three herds, but most frequently in one group in which six young were born to three females during 2 weeks in May, 1979. These juveniles often formed a snapping and jostling horde at the rear of one of the females, with all juveniles struggling to reach a teat. The females seemingly ignored the comotions and never interceded. 
There is excellent experimental evidence that predation exerts a significant effect on peccary populations at the 3-Bar (G. Day, Arizona Game and Fish Department, pers. comm.). We observed three encounters between herds and predators (two with coyotes, Canis latrans, one with a bobcat, Lynx rufus), and in each instance there was evidence of coordinated and cooperative defense. In both coyote encounters one or two adult peccaries moved forward and drove them away. In one of these incidents the coyotes were within $3 \mathrm{~m}$ of the herd and other adults clustered around the juveniles and led them away. In the bobcat encounter, the entire herd bunched together and walked as a group toward the cat. We did not see the outcome of this confrontation because of darkness.

These few observations indicate that peccaries were capable of cooperative defense against predators. Their response to humans was immediate flight and we suspected that flight also would be the response to larger predators. However, in 13 instances in which herds retreated in a line, juveniles always were together close to the front of the line, usually behind the first or second adult. Even in retreat, there appeared to be an organized form of defense that favored protection of juveniles. This was not so, however, when herds ran in a bunch or scattered in response to an alarm. In these situations, juveniles frequently were left behind, as reported by Knipe (1957), Schweinsburg (1969), and Sowls (1974).

Close feeding, defined as situations in which one animal approached another feeding individual and fed next to it, its mouth no more than one head width away from the other, occurred among adults and between adults and juveniles (Fig. 7). Such behavior certainly was a form of food sharing and might be called "altruistic." Close feeding alternatively might be interpreted as a dominant animal exploiting a food source discovered by a subordinate. However, if this were so, it would be difficult to explain why the dominant animal would not drive the subordinate away and appropriate the entire food source. Also, there were many instances of close feeding that involved several animals feeding from the same plant. Eddy (1959) believed that close feeding occurred commonly.

TABLE 3. Summary of interactions in which sexual behavior occurred between collared peccaries, central Arizona, 1978-1980.

\begin{tabular}{|lc|}
\hline Interaction & N \\
\hline Female resisted male courtship by withdrawal or aggressive response, no mounts or attempted mounts & 17 \\
Female did not resist courtship, may have shown amicable behavior, no mounts or attempts & 28 \\
Male attempted mount, female aggressive response & 2 \\
Male attempted mount, no female aggression & 6 \\
Male mounted, female active role in courtship & 18 \\
Male mounted with pelvic thrusts, male active role in courtship & 2 \\
Male mounted with pelvic thrusts, female active role in courtship & 1 \\
Total & 74 \\
\hline
\end{tabular}

Males usually took the active role in courtship and mating but there were a few instances in which females were more active (Table 3). Of 74 sexual encounters, 12 involved at least one animal in addition to the original two interactants. In five of the 12 incidents, other animals were within $2 \mathrm{~m}$ of the courting pair, but there was no apparent hostility. In the other seven incidents there was mild hostility as one animal displaced, or attempted to displace another. Absolutely no fighting was observed. In two of the seven incidents, the female took an active role in deciding the outcome of the attempted displacement by driving the approacher away. In one incident the female copulated with one male, then actively courted and eventually copulated with a second male, with the first male standing 3-4 $\mathrm{m}$ away; there was no observable hostility. Finally, there were 24 displacements not obviously connected with courtship, and 14 
of these occurred during 4 days when there was sexual activity. Thus, there was a trend toward an increase in agonistic behavior when a herd female was in estrus, but this increase was not always observable. There was little observable competition among males over receptive females.

\section{DISCUSSION}

Biology of T. tajacu relevant to social behavior.--There are three extant species of peccaries, the collared, the white-lipped (Tayassu pecari), and the Chacoan (Catagonus wagneri) (Wetzel et al., 1975; Wetzel, 1977b). All are confined to the Neotropics except for the slight extension of $T$. tajacu into the Nearctic. The family probably diverged from primitive pigs (Suidae) near the Eocene-Oligocene border (Herring, 1972; Romer, 1966; Thenius, 1970; Woodburne, 1969a). Fossils are known from Asia (Pickford, 1976), Africa (Hendey, 1976), North America (Gidley, 1921; Guilday et al., 1971; Lundelius, 1960), and South America (Patterson and Pascual, 1972; Woodburne, 1969b). However, the family probably did not reach South America until the end of the Pliocene (Patterson and Pascual, 1972), and the northernmost fossils of T. tajacu are from the Pleistocene of Guatemala (Woodburne, 1969b ). Collared peccaries likely originated in South America, spent most of their evolutionary history there (Wetzel, 1977b; Woodburne, 1968), and only within the Recent radiated into North America. This supposition is corroborated by temperature and water physiology of this species, which is that of typical tropical mammals (Zervanos, 1972, 1975; Zervanos and Day, 1977; Zervanos and Hadley, 1973). Peccaries have a narrow thermal neutral zone, poorly insulating pelage, and little ability to conserve water.

Peccaries differ from pigs in their reproductive biology. Members of the Suidae bear large litters of somewhat altricial young; collared peccaries bear 1 to 3 (usually 2) precocial young (Low, 1970; Sowls, 1966). The small litter size in peccaries almost certainly is a function of the advanced stage of development at which young are born. Precocial young probably were selectively advantageous because they could follow the mother and the herd shortly after birth. Peccary females, when they give birth, spend 1 day or less apart from their herds. Female S. scrofa, however, are isolated from conspecifics for a period of weeks (Grundlach, 1968). The small precocial litters of collared peccaries are interpreted most plausibly as an adaptation that allows parturient females to rejoin their herds quickly.

This adaptation, the presence of two social acts (the mutual rub and the low grunt) seemingly designed to promote group cohesion, and the distress shown by animals separated from their herds, suggest maintenance of small interanimal distances was selected strongly in the evolution of $T$. tajacu. Because this species is a common prey item of medium- to large-sized carnivores in Central and South America (Enders, 1935; Leopold, 1959; Wetzel, 1977a), we suggest that peccaries initially were selected to stay close to conspecifics for protection from predation.

Social behavior.--Agonistic interactions occurred at a much lower frequency than amicable ones and only $13.7 \%$ of all agonistic behavior observed involved physical contact. Ten bites were observed, but no wounds or bleeding as a result of these could be detected. Schweinsburg and Sowls (1972) observed fighting in forced encounters between captive animals and described several potentially dangerous patterns, including the "charge," uninhibited biting, the "whirl around," and the "throw down." Neither we nor Knipe (1957) observed fighting of this sort. Schweinsburg and Sowls (1972) also did not observe fighting in the wild. If the severe fighting Schweinsburg and Sowls (1972) observed among captive animals occurs in natural populations, it must be extremely rare. In contrast, fierce fighting, though infrequent, has been observed in two wild suids, Sus scrofa (Fradrich, 1974) and Phacochoerus aethiopicus (Frädrich, 1965).

Canine teeth of collared peccaries are not modified as slashing weapons, as are the laterally directed, procumbent canines of suids (Herring, 1972). They are, nonetheless, potentially dangerous, and may 
deter large predators (Van Pelt, 1977). Wild peccaries thus would be expected to avoid uninhibited fights unless over a valuable resource, such as sexual access to several estrous females (Dawkins, 1976; Geist, 1966, 1978; Maynard-Smith, 1974; Maynard-Smith and Parker, 1976). A further reduction in fighting would be expected if herd members were closely related; the stability in membership suggests that peccary herds may indeed comprise closely related individuals. Probably, males do not compete vigorously over estrous females because, for any male, the gain in fitness attained by excluding another (related) male from sexual activity is small.

The lack of sexual dimorphism in body size, canine size, or other characters that might influence fighting ability (Miller, 1970; Sowls, 1966; Woodburne, 1968) also reflects an evolutionary history of reduced male-male competition. Sexual selection appears to have had little effect on male peccary anatomy. In contrast, ungulate species in which there is polygyny and strong male-male competition show marked sexual dimorphism in body size and in fighting and display organs (Alexander et al., 1979). Sowls (1966) and Bissonette (1976) suggested that more competition exists in peccaries than is apparent, and that it is masked by well-established dominance hierarchies that assure mating priority to dominant males. However, observations in this study indicated that exclusive courtship and mating rights may not exist. Also, no field studies of $T$. tajacu quantitatively documented a dominance hierarchy.

Peccary herds are coherent and essentially closed social units. Subadults seemingly are not driven away from the social group as usually occurs in suids (Bradley, 1971; Frädrich, 1965; Grundlach, 1968; Leuthold, 1977). There are no reports of juvenile peccary dispersal in the literature, and we saw none. Also, we saw no social interactions (such as chases) between adults and juveniles that might have led to juvenile dispersal. Adult individuals occasionally leave herds, however. Schweinsburg (1969) found limited evidence for this; Day (pers. comm.) accumulated 9 years of data on movements between herds by radio-collared adults and found an adult emigration rate of $10.8 \%$ with a slight tendency for males to emigrate more frequently than females. Consistent with this low rate are observations that dispersing animals may find it difficult to gain acceptance in a new herd. Bissonette (1976) saw no instances in which strange individuals successfully joined herds. We saw one herd in which an animal trailed behind and repeatedly was chased by members of the group, from December 1978 until observations of this herd were ended in June 1979. After nearly 7 months, the individual still encountered strong hostility from the herd it attempted to join.

Tayassu tajacu is a tropical rainforest species that, at the northern extreme of its range, retains a pelage, temperature and water-balance physiology, and reproductive cycle characteristic of the tropics. We suggest that its behavior also reflects its tropical origin, where gregariousness was favored selectively as an antipredator adaptation (Bertram, 1978; Hamilton, 1971; Rubenstein, 1978). Contact-promoting actions based on hearing and olfaction probably were selected as the most effective ways of maintaining herd integrity in the dense rainforest understory. It is likely that this, and other behavior designed to maintain small interindividual distances, was established first and that such proximity, extending across generations, allowed kin selection (Hamilton, 1964) to reduce male-male competition and to favor evolution of the cooperative behavior described. However, before kin selection is considered further as an explanation for the specialized social traits of this peccaries, information on the degrees of relatedness among herd members will be required.

\section{ACKNOWLEDGMENTS}

We thank the Arizona Department of Game and Fish for unrestricted access to the 3-Bar. K. Byers drew the figures and assisted with field work and data analysis. G. Day, V. Supplee, R. Horejsi, A. LeCount, and $\mathrm{J}$. Wegge generously shared data, observations, and their knowledge of the area. Crucial logistical help was given by R. Betz and R. Smith. This research was supported in part by a National Science 
Foundation grant (BNS-23643) to M. Bekoff, and by Sigma Xi and University of Colorado Graduate School grants to J. Byers. We thank C. Bock for his early advocacy of peccary research and L. Sowls for suggesting the 3-Bar as a possible study site.

\section{LITERATURE CITED}

ALEXANDER, R. D., ET AL. 1979. Sexual dimorphisms and breeding systems in pinnipeds, ungulates, primates, and humans. pp. 402-435, in Evolutionary biology and human social behavior: an anthropological perspective (N. A. Chagron and W. Irons, eds.). Duxbury Press, North Scituate, Massachusetts, $623 \mathrm{pp}$.

ALTMANN, J. 1974. Observational study of behaviour: sampling methods. Behaviour, 49:227-267.

BEKOFF, M. 1977. Social communication in canids: evidence for the evolution of a stereotyped mammalian display. Science, 197:1097-1099.

BERTRAM, B. C. R. 1978. Living in groups: predators and prey. Pp. 64-96, in Behavioural ecology (J. R. Krebs and N. B. Davies, eds.). Sinauer Assoc., Sunderland, Massachusetts, 494 pp.

BIGLER, W. J. 1964. The seasonal movements and herd activities of the collared peccary Pecari tajacu in the Tortolita Mountains. Unpubl. M.S. thesis, Univ. Arizona, Tucson, 52 pp.

---. 1974. Seasonal movements and activity patterns of the collared peccary. J. Mamm., 55:851-855.

BISSONETTE, J. A. 1976. The relationship of resource quality and availability to social behavior and organization in the collared peccary. Unpubl. Ph.D. dissert., Univ. Michigan, Ann Arbor, 134 pp.

---. 1978. The influence of extremes of temperature on activity patterns of peccaries. Southwestern Nat., 23:339-346.

BRADLEY, R. M. 1971. Warthog (Phacochoerus aethiopicus Pallas) burrows in Nairobi National Park. E. African Wildl. J., 9:149-152.

DAWKINS, R. 1976. The selfish gene. Oxford Univ. Press, New York, Oxford, 224 pp.

EDDY, T. A. 1959. Foods of the collared peccary Pecari tajacu sonoriensis (Mearns) in southern Arizona. Unpubl. M.S. thesis, Univ. Arizona, Tucson, $102 \mathrm{pp}$.

ELLISOR, J. E., AND W. F. HARTWELL. 1969. Mobility and home range of collared peccary in southern Texas. J. Wildl. Mgmt., 33:425-427.

ENDERS, R. K. 1930. Notes on some mammals from Barro Colorado Island, Canal Zone. J. Mamm., 11:280-292.

---. 1935. Mammalian life histories from Barro Colorado Island, Panama. Bull. Mus. Comp. Zool., Harvard Univ., 78:385-502.

FAGEN, R. M., AND R. N. GOLDMAN. 1977. Behavioral catalogue analysis methods. Anim. Behav., 25:261-274.

FRÄDRICH, H. 1965. Zur Biologie und Ethologie des Warzenschweines (Phacochoerus aethiopicus Pallas) unter Berücksichtigung der Verhaltens anderer Suiden. Z. Tierpsychol., 22:328-393.

--. 1967. Das Verhalten der Schweine (Suidae, Tayassuidae) und Fluß pferde (Hippopotamidae). Handbuch der Zoologie, 10:1-44.

---. 1974. A comparison of behavior in the Suidae. pp. 133-143, in The behaviour of ungulates and its relation to management (V. Geist and F. Walther, eds.). IUCN, Morges, Switzerland, $511 \mathrm{pp}$.

GEIST, V. 1966. The evolution of horn-like organs. Behaviour, 27:175-214.

---. 1977. A comparison of social adaptations in relation to ecology in gallinaceous bird and ungulate societies. Ann. Rev. Ecol. Syst., 8:193-207.

---. 1978. On weapons, combat, and ecology. pp. 1-30, in Aggression, dominance and individual spacing (L. Krames, P. Pilner, and T. Alloway, eds.). Plenum Publ., New York, 173 pp.

GIDLEY, J. W. 1921. Pleistocene peccaries from the Cumberland Cave deposit. Proc. U.S. Natl. Mus., 57:651-678. 
GRUNDLACH, V. H. 1968. Brutfürsorge, Brutpfiege, Verhaltensontogenese und Tagesperiodik beim Europäischen Wildschwein (sus scrofa L.). Z. Tierpsychol., 25:955-995.

GUILDAY, J. E., H. W. HAMILTON, AND A. D. McCRADY. 1971. The Welsh Cave peccaries (Platygonus) and associated fauna, Kentucky Pleistocene. Ann. Carnegie Mus., 43:249-320.

HAMILTON, W. D. 1964. The genetical evolution of social behaviour. J. Theor. Bioi., 7:1-52.

--. 1971. Geometry for the selfish herd. J. Theor. Bioi., 31:295-311.

HENDEY, Q. B. 1976. Fossil peccary from the Pliocene of South Africa. Science, 192:787-789.

HERRING, S. W. 1972. The role of canine morphology in the evolutionary divergence of pigs and peccaries. J. Mamm., 53:500-512.

JENNINGS, W. S., AND J. T. HARRIS. 1953. The collared peccary in Texas. Texas Game Fish Comm., Austin, Texas, $31 \mathrm{pp}$.

KILTIE, R. A. 1980. Seed predation and group size in rain forest peccaries. Unpubl. Ph.D. dissert., Princeton Univ., Princeton, $170 \mathrm{pp}$.

KNIPE, T. 1957. The javelina in Arizona. Wild!. Bull., Arizona Game Fish Dept. 2:1-96.

LEOPOLD, A. S. 1959. Wildlife of Mexico. The game birds and mammals. Univ. California Press, Berkeley, $568 \mathrm{pp}$.

LEUTHOLD, W. 1977. African ungulates. A comparative review of their ethology and behavioral ecology. Springer-Verlag, Berlin, Heidelberg, New York, 307 pp.

LOW, W. A. 1970. The influence of aridity on reproduction of the collared peccary (Dicotyles tajacu (Linn.)) in Texas. Unpubl. Ph.D. dissert., Univ. British Columbia, Vancouver.

LUNDELIUS, E. L. 1960. Mylohyus nasutus. Long-nosed peccary of Texas Pleistocene. Bull. Texas Mem. Mus., 1:9-40.

MAYNARD-SMITH, J. 1974. The theory of games and the evolution of animal conflicts. J. Theor. Bioi., 47:209-221.

MAYNARD-SMITH, J., AND G. A. PARKER. 1976. The logic of asymmetric conflicts. Anim. Behav., 24:159-175.

MILLER, F. W. 1930. Notes on some mammals of southern Matto Grosso, Brazil. J. Mamm., 11:10-22.

MILLER, S. J. 1970. Sex and age determination of the collared peccary (Dicotyles tajacu) by skull characteristics. Unpubl. M.S. thesis, Univ. Arizona, Tucson, 34 pp.

MINNAMON, P. J. 1962. The home range of the collared peccary Pecari tajacu (Mearns) in the Tucson Mountains. Unpubl. M.S. thesis, Univ. Arizona, Tucson, 42 pp.

NEAL, B. J. 1959. A contribution on the life history of the collared peccary in Arizona. Amer. Midland Nat., 61:177-190.

PATTERSON, B., AND R. PASQUAL. 1972. The fossil mammal fauna of South America. pp. 247-309, in Evolution, mammals and southern continents. (A. Keast, E. Erk, and B. Glass, eds.). State Univ. New York Press, Albany, 543 pp.

PICKFORD, M. 1976. A new species of taucanamo (Mammalia: Artiodactyla: Tayassuidae) from the Siwaliks of the Potwar Plateau, Pakistan. Pakistan J. Zool., 8:13-20.

ROMER, A. S. 1966. Vertebrate paleontology. Third ed., Univ. Chicago Press, 468 pp.

RuBENSTEIN, D. I. 1978. On predation, competition and the advantages of group living. pp. 205-231, in Perspectives in ethology (P. H. Klopfer and P. P. G. Bateson, eds.). Plenum Publ., New York, 3:1-277.

SCHWEINSBURG, R. E. 1969. Social behavior of the collared peccary (Pecari tajacu) in the Tucson mountains. Unpubl. Ph.D. dissert., Univ. Arizona, Tucson, 115 pp.

---. 1971. Home range, movements, and herd integrity of the collared peccary. J. Wildl. Mgmt., 35:455460.

SCHWEINSBURG, R. E., AND L. K. SOWLS. 1972. Aggressive behavior and related phenomena in the collared peccary. Z. Tierpsychol., 30:132-145.

SOKAL, R. R., AND R. J. ROHLF. 1969. Biometry. W. H. Freeman and Co., San Francisco, 776 pp. 
SOWLS, L. K. 1966. Reproduction in the collared peccary (Tayassu tajacu). pp. 155-172, in Comparative biology of reproduction in mammals (I. W. Rowlands, ed.). Acad. Press, London, $559 \mathrm{pp}$.

---. 1974. Social behavior of the collared peccary Dicotyles tajacu (L.). pp. 144-165, in The behavior of ungulates and its relation to management (V. Geist and F. Walther, eds.). IUCN, Morges, Switzerland, $511 \mathrm{pp}$.

THENIUS, E. 1970. Zur Evolution and Verbreitungsgeschichte der Suidae (Artiodactyla: Mammalia). Z. Saugetierk., 35:321-342.

VAN PELT, A. F. 1977. A mountain lion kill in southwest Texas. Southwestern Nat., 22:271.

WETZEL, R. M. 1977a. The chacoan peccary Catagonus wagneri (Rusconi). Bull. Carnegie Mus. Nat. Hist., 3:1-36.

---. 1977b. The extinction of peccaries and a new case of survival. Ann. New York Acad. Sci., 288:538544.

WETZEL, R. M., R. E. DUBOS, R. L. MARTIN, AND P. MYERS. 1975. Catagonus, an "extinct" peccary, alive in Paraguay. Science, 189:379-381.

WILSON, E. 0. 1975. Sociobiology. The new synthesis. Harvard Univ. Press, Cambridge, 697 pp.

WOODBURNE, M. 0. 1968. The cranial myology and osteology of Dicotyles tajacu, the collared peccary, and its bearing on classification. Mem. So. California Acad. Sci., 7:1-48.

---. 1969a. Systematics, biogeography and evolution of Cynorca and Dyseohyus (Tayassuidae). Bull. Amer. Mus. Nat. Hist., 141:271-356.

---. 1969b. A late Pleistocene occurrence of the collared peccary, Dicotyles tajacu, in Guatemala. J. Mamm., 50:121-125.

ZERVANOS, S. M. 1972. Thermoregulation and water relations of the collared peccary (Tayassu tajacu). Unpubl. Ph.D. dissert., Arizona State Univ., Tempe, 160 pp.

---. 1975. Seasonal effects of temperature on the respiratory metabolism of the collared peccary (Tayassu tajacu). Comp. Biochem. Physiol., 50A:365-371.

ZERVANOS, S. M., AND G. I. DAY. 1977. Water and energy requirements of captive and free-living peccaries. J. Wildl. Mgmt., 41:527-532.

ZERVANOS, S. M., AND N. F. HADLEY. 1973. Adaptational biology and energy relationships of the collared peccary (Tayassu tajacu). Ecology, 54:759-774. 